\title{
The impact of the terrorism on North African tourism
}

\author{
Florentina-Stefania NEAGU \\ The Bucharest University of Economic Studies, Bucharest, Romania \\ stefanianeagu15@gmail.com
}

\begin{abstract}
Tourism is one of the most important sector of the national economy and in the same time is the main reason for which the tourists visit the North African states. In 2015, the total contribution of North African tourism represent 10.8\% from GDP registering an increase of $1.4 \%$ compared to 2014, also the contribution of tourism to employment was $10.4 \%$ in 2015. But this increase was affected by the terrorist attacks in Algeria, Egypt, Libya, Morocco and Tunisia. According to Global Terrorism Index for 2016, these countries are in the ranking of states with the highest impact of terrorism. Security situation in 2015 is the following: 947 incidents, 1198 deaths, 1603 injured, 264 property damages. This situation greatly influences the decision of tourists to travel in these countries. For demonstrate what is the impact on terrorism in this region have been analized the data bases of World Travel and Tourism Council, Council and Foreign Relations and Global Terrorism Database for the period 2010-2015. If the terrorist attacks continue in the next years not only the tourism will be affected but also the activities of its associates.
\end{abstract}

Keywords: tourism, tourists, terrorism, security.

\section{Introduction}

The tourism industry annually attracts millions of tourists who want to discover new places, have fun and practice sports. The purpose of tourism is to satisfy the needs of tourists by providing them comfortable accommodation, food of the highest quality and providing entertainment. To the global economy, tourism had a direct contribution of $\$ 2.23$ trillion in 2015 and the North Africa of $\$ 71$ billion (Statista, 2015), a high value if the continent-wide African contribution was $\$ 180$ billion (World Trade and Tourism Council, 2015).

According to Africa Monitor Tourism over the years countries such as Egypt, Morocco, Tunisia recorded a huge number of tourists followed by other African countries like Cameroon, Tanzania, Sierra Leone, Cape Verde, Seychelles. Most of tourists visiting the North African countries from Europe, USA, China and other Arab countries, but the number began to decline after the Arab Spring.

Also, according to booking company data Expedia.Inc, ticket bookings and tour packages made by foreigners were tourists at three destinations Morocco, Tunisia and Egypt followed by South Africa and the city with the most reservations was Marrakech.

In respect of the countries of origin and the purpose of travel in North African countries, the top three are United States of America, United Kingdom and France, whose citizens come to these countries for business. According to data released by Statista, the number of business visits from UK was 15.000 persons in Egypt, 8.000 persons in Morocco, 6.000 persons in Tunisia, Algeria and Libya 3.000 persons. While Chinese citizens visiting Algeria and Egypt.

In the period 2001-2010, two states went through a similar situation, Egypt has seen a threefold increase in the number of tourists reached 14.7 million tourists, but after 2011 the number of tourists has dropped by a third, also Tunisia increases until 2010 and then a sharp decline against the background of tensions generated overthrowing dictatorships. At the opposite, Algeria is not as developed in terms of tourism and its neighbors tourist arrivals related visits to families. 


\section{Political situation}

States of North Africa, Algeria, Egypt, Libya, Morocco and Tunisia have many common elements, such as Arabic language, the Muslim religion, are former colonies (Lewis, 1995), are countries where tourism contributes to economic development. Egypt, Morocco and Tunisia are among the most beautiful sights in the world. These countries have undergone political changes over the years and their capitals were extensive street demonstration scenes that resulted in deaths and injuries, and removal from office of dictators.

Nevertheless, efforts are made to maintain a state of peace and further economic development, but this has not succeeded this in all countries. Currently, tensions persist and have deepened between Sunnis and Shiites religious and manage these fund terrorist organizations much easier to carry out their terrorist acts. On the other hand, the intensification of terrorist attacks taking place against the background great powers USA and Russia interventions in order to destroy the Islamic State group. But the continuation of the war in Syria, Iraq and Libya will lead to political instability on the medium and long term, stagnating regional economic development and increased flow of refugees and the neighboring countries Algeria, Egypt, Tunisia will be affected by internal tensions and terrorist attacks. In North Africa and the Middle East terrorist acts continue because Persian Gulf states (Intelligence Risk Assessment, 2015) have great resources of oil and also supports armed opposition in Syria, the tribes Sunni in Iraq and military governments in Egypt, Libya and Yemen.

As shown in Table 1 the five states have many strengths which through the adoption of political and social measures, can lead in the next years, to insecurity which currently endanger the country's image to be removed and weaknesses visible diminished. Also, these countries have some common characteristics that distinguish them from the other African countries, namely the tourism potential, proximity to the European market and possession of large quantities of hydrocarbons.

Table 1. Strengths and weaknesses of North African region

\begin{tabular}{|c|c|c|}
\hline Country & Strengths & Weaknesses \\
\hline Algeria & $\begin{array}{l}\text {-Significant reserves of oil and } \\
\text { gas } \\
\text {-Potential in the fields of } \\
\text { renewable energies and tourism } \\
\text {-Solid external financial situation } \\
\text { (very low external indebtedness, } \\
\text { significant foreign exchange } \\
\text { reserves) }\end{array}$ & $\begin{array}{l}\text {-High dependency on } \\
\text { hydrocarbons and problems with } \\
\text { the utilisation of this income } \\
\text {-Fracture lines between the } \\
\text { government and the population } \\
\text {-High unemployment rates } \\
\text { amongst the young }\end{array}$ \\
\hline Egypt & $\begin{array}{l}\text {-Tourism potential } \\
\text {-Political and financial support } \\
\text { from the Gulf monarchies and } \\
\text { western countries }\end{array}$ & $\begin{array}{l}\text {-Poverty ( } 40 \% \text { of the population) } \\
\text { and high unemployment } \\
\text {-Low level of foreign exchange } \\
\text { reserves }\end{array}$ \\
\hline Libya & -Large oil and gas reserves & $\begin{array}{l}\text {-Economy highly concentrated } \\
\text { and dependent on the oil and gas } \\
\text { sector } \\
\text {-Extremely uncertain political } \\
\text { transition together with critical } \\
\text { security problems } \\
\text { - Very difficult business climate }\end{array}$ \\
\hline Morocco & $\begin{array}{l}\text {-Macroeconomic stability policy } \\
\text {-High tourism potential } \\
\text {-Strategy to move upscale and } \\
\text { diversify production in }\end{array}$ & $\begin{array}{l}\text {-Economy very dependent on } \\
\text { performances in the agricultural } \\
\text { sector } \\
\text {-Significant social and regional }\end{array}$ \\
\hline
\end{tabular}




\begin{tabular}{|c|l|l|}
\hline & $\begin{array}{l}\text { automotive,aeronautics, } \\
\text { electronics,offshoring, chemicals, } \\
\text { etc }\end{array}$ & $\begin{array}{l}\text { disparities } \\
\text {-The poverty rate remains high } \\
\text { even though it is falling } \\
\text {-Weakness in productivity and } \\
\text { competitiveness } \\
\text {-High unemployment rate }\end{array}$ \\
\hline Tunisia & $\begin{array}{l}\text {-Natural resources (gas, } \\
\text { phosphates) and agricultural and } \\
\text { tourism resources } \\
\text {-Gradual political transition } \\
\text {-Proximity to the European } \\
\text { market and Association } \\
\text { Agreement with the EU }\end{array}$ & $\begin{array}{l}\text {-Strong social and geographic } \\
\text { inequalities } \\
\text {-High unemployment, mainly } \\
\text { amoung young people } \\
\text {-Economic importance of } \\
\text { agriculture } \\
\text {-Tourism sector facing political } \\
\text { and security issues and greater } \\
\text { competition }\end{array}$ \\
\hline
\end{tabular}

Source: Coface, 2017.

\section{The objectives of terrorist groups}

The objectives of the terrorists are influenced by motivations and the ideologies of each terrorist organization. Their objectives are tactical and strategic (Gray and Stines, 2012), so the tactical objectives aim to attract the attention of the media generating strategic costs to enemies (terrorists knowing that terrorist acts determines the allocation of money by governments to protect the population), they want to stimulate an aggressive reaction from governments, to divide the society and they want to obtain material benefits (through kidnapping people and demand ransom in exchange for freeing, drug trafficking and people).

The strategic objectives focuses on obtaining recognition of the terrorist organization locally, regionally and internationally, raising fears of large-scale, destruction of communication infrastructure in order to create uncertainty among the population that authorities can protect them, influencing government decisions, discourage foreign investments, humanitarian assistance programs and tourism.

These objectives have a big impact on tourism (DePuma, 2015) by the fact that terrorists as targets the tourists, places and institutions that they visit, resorts or places of residence of politicians, businessmen whilst being visited in the same time from a large number of international tourists.

The motivation of terrorist for the touristic objectives is that the image of terrorist organizations increase (Stremtan and Susman, 2006), especially because the tourism is the symbol of capitalism and an attack or kidnapping of tourists a western country enemy is a direct hit to the enemy state.

Also, attacking of touristic objectives that represent symbols of tourism of a country, directly lead to a decreased number of tourists who choose either to remain in their country or choose a safe destination, and indirectly lead to instability of the balance of payments and the business environment unsafe.

\section{The impact of terrorist attacks on tourism}

Producing a terrorist attack in a country which results with more deaths and injuries determine a decline of tourism by decreasing the acquisition of travel packages for those destinations, coupled with the decrease of the booking plane tickets and eventually even leading to the postponement or cancellation of meetings, international conferences programmed in these areas. 
As shown in Fig.1 North African countries were visited by a large number of tourists in the period before the Arab Spring, but revolts street followed by the intensification of terrorist attacks has made that the number of tourists to decline significantly.

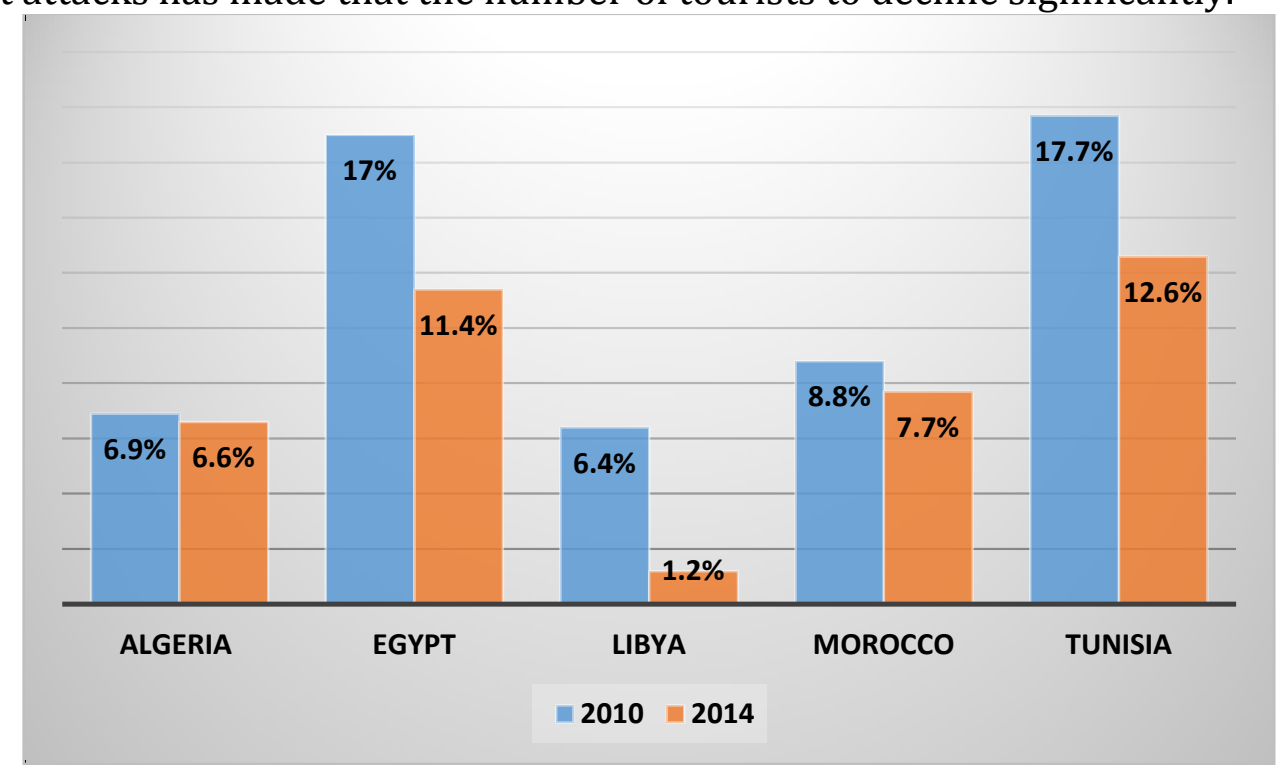

Figure 1. Contribution of tourism to GDP 2010-2014

Source: World Data Atlas.

States from North Africa most affected by the terrorist attacks in 2016, according to Global Terrorism Index were Egypt and Libya, positioning in the ranking of 164 countries, on the 9th and 10th in the rankings, while Tunisia has been ranked on 35th, Algeria and Morocco ranked on 42nd and 95th.

Currently, most attacks in Egypt have targeted the security forces, their installations, government buildings, tourists and the aircraft hijacking. In October 2015, the group Sinai Province of the Islamic State claimed hijacking the plane with 224 people on board and which has resulted with the plane crash in Northern Sinai and the death of all persons on board. After this incident Russia and UK have decided to suspend all flights to the Red Sea resort. Three months later, in January 2016 three foreign tourists were stabbed two Islamic militants who stormed a hotel in the resort of Hurghada in Egypt.

According to Egyptian Tourism Ministry, the monthly losses following the aircraft hijacking are worth $\$ 173$ million. Also, according to Central Agency for Public Mobilization and Statistics (CAPMAS) the first three countries that contributed to the Egyptian tourism in 2014 were Russia, UK and Germany. More than that, Russians tourists represent 67,9 \% of all foreign tourists who visited Egypt in 2015. The Central Bank of Egypt, announced at the end of December 2016 the setting up a fund worth $\$ 227$ million for the improvement of hotels, tourist resorts and other tourism facilities.

The purpose of these measures is to attract new tourists and to encourage the foreign investors. Especially since 2016, according to the interview given by Hossam Akawy, a tourism expert and a member of the Tourism Investors' Association in the Red Sea for the Al-Monitor Newspaper said that Germany, Denmark and Finland lifted their travel bans on flights to Egypt's Sharm el-Sheik.

In Tunisia have been two major incidents with tourists in March 2015, members of Jund al-Khilafah group attacked tourists at Bardo National Museum in the capital Tunis, killing 24 people and injuring 42 people. A member of the same terrorist group 
opened fire on Riu Imperial Marhaba Hotel tourists to the city of Sousse, the attack has been ended with 39 dead and 36 wounded.

According to the Global Terrorism Database, Libya were also very affected by terrorist attacks, so that only in 2015 have been over 432 incidents that resulting in 454 deaths and 660 injured. Following the unstable security situation, the latest foreign company operating in Libya airline suspended all flights. Turkish Airlines has suspended PICBE | 1085 all flights to Misrata after prior suspend flights to Tripoli, Benghazi and Sebha.

Even Libyan Afriqiyah Airways national company has suffered after his plane with 118 people aboard was hijacked on December 23, 2016 while traveling from Sebha to Tripoli, the pilot of the plane was forced to land in Malta. Following these incidents states inform its citizens through foreign ministries alerts on risks that may be put if they traveling to a country affected by terrorist attacks. More than that, the British government announced he doesn't make a substantial concessions on the release the British citizens were kidnapped, considering that paying ransom and the release of prisoners will increase kidnappings for foreign citizens.

As shown in Fig.2 the security situation on the medium and long term it is uncertain in these countries in the context of nationwide exist the Islamic State group and its affiliated groups that commit terrorist attacks almost daily. Also, as it can see on the map, the terrorist groups are positioned near the borders. This positiong ensures them access to the Mediterranean Sea and Red Sea, at the same time Egyptian and Libyan ports with access to the Mediterranean Sea are starting or transit points of illegal immigrants to Europe.

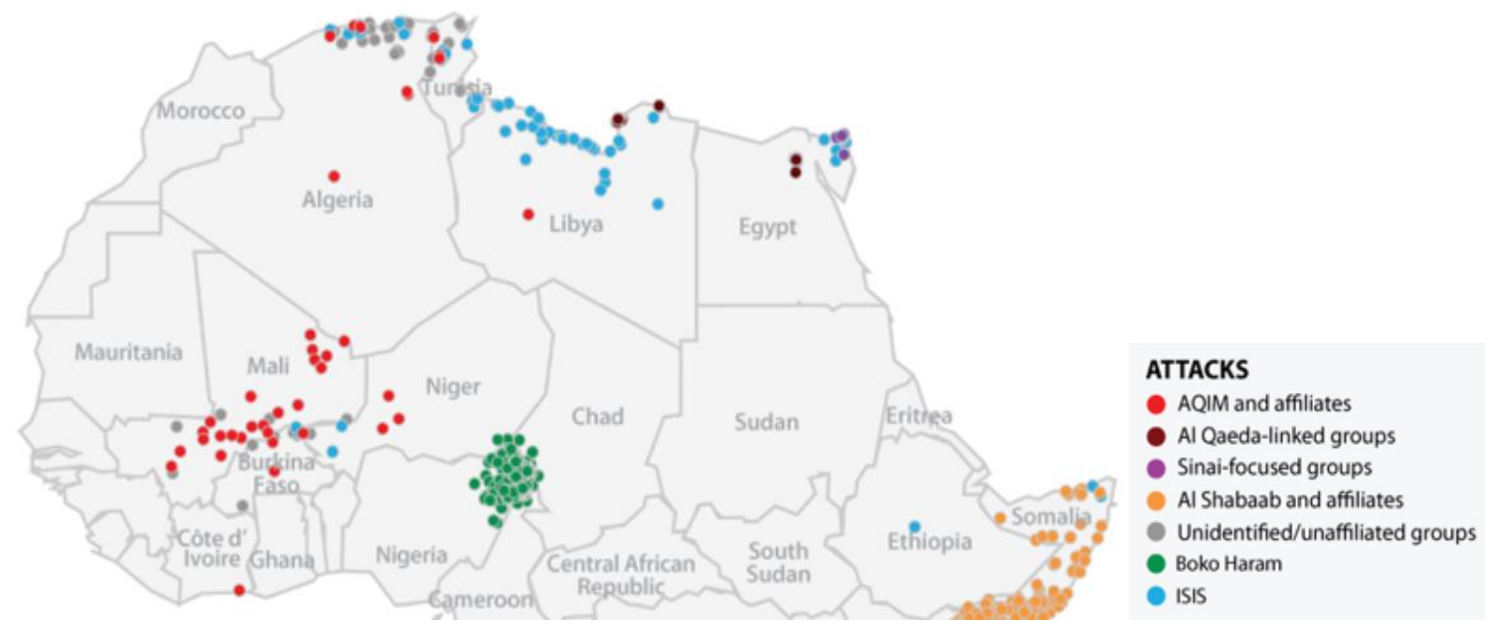

Figure 2. The Activity of Militant Islamist Groups in North Africa in 2016

Source: Africa Center for Strategic Studies.

In the last five years many citizens affected by revolts street and terrorist attacks have left for other safer countries on the African continent or in Europe, because the situation has been worsened from year to year. Off all states, Libya is the insecure state due to the fact that following the eliminating the dictator Muammar Gaddafi, the political, military, and security situation is uncertain, in the present the country is ruled by two governments, one in Tripoli and one in the Tobruk.

On the other hand, from 2014 have increased the number of foreign fighters (Alexander, 2016) on the territory of these countries, which leads to consolidation of indigenous extremist groups and local militias. In this sense, the Islamic State group in Libya has arranged a training ground for its members around the city of Sirte. 
As shown in Fig. 3, following the low tourism demand hotels, tourism agencies and tourism resorts have reduced the number of employees which has led to an increase to the unemployment rate from $11.9 \%$ in 2010 to $13.6 \%$ in 2015 (World Data Atlas).

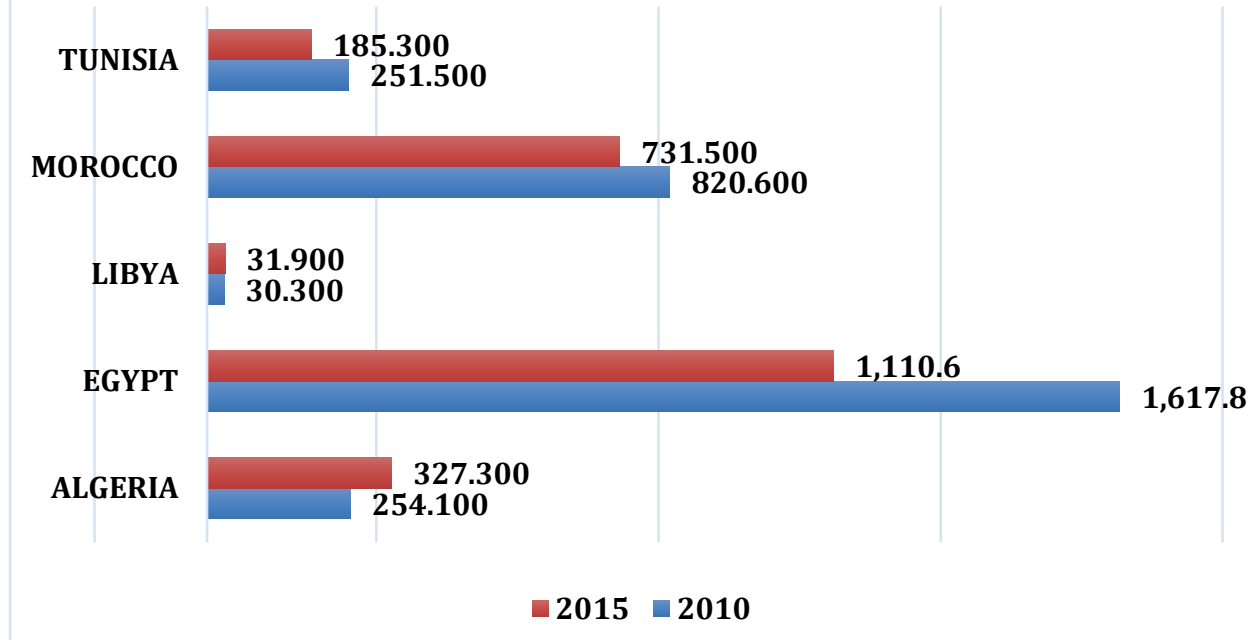

PICBE | 1086

Figure 3. Employees in tourism 2010-2015

Source: World Travel and Tourism Council.

Also, in the period 2010-2015 (Fig.4) we can see that leisure spending and business spending have dropped by a few percent while the domestic spending have increased.

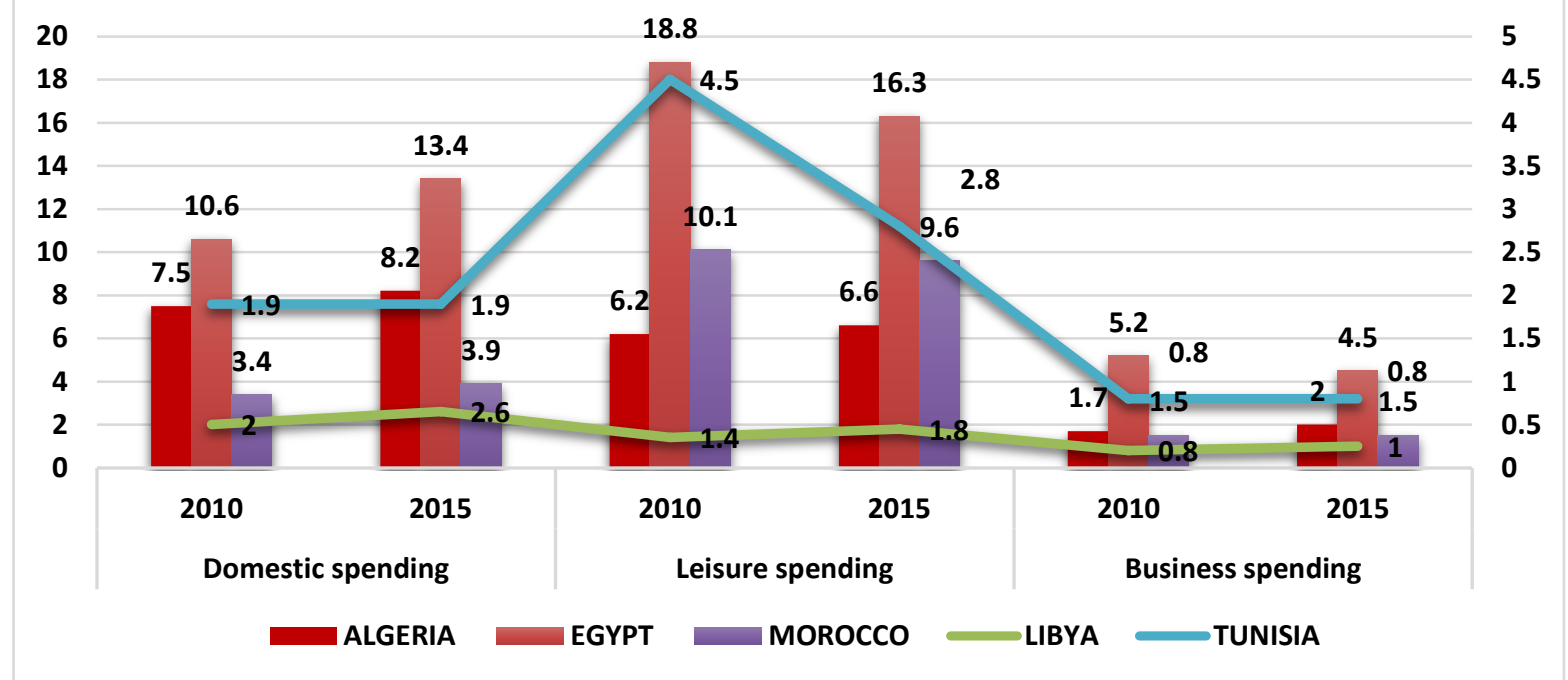

Figure 4. Spending on tourism 2010-2015 (US\$ bn)

Source: World Data Atlas.

Following the terrorist attacks that occurred globally, the organization International SOS has realised a survey of over 1.000 managers, responsible for their organization's travel risk (these organizations are: air companies, tourism agencies, hotels, commercial companies). The survey has shown that the most important risk mitigation activities were: reinforced travel security measures, introduced pre-trip advisory emails, implemented travel safety training for employees and implemented programmes to locate tourists.

According to African Hotel Index Value which analyzed informations on 21 African hotels markets. This index offer projections on market dynamics and hotel value changes. In the top of 21 African countries Egypt ranked on the 8th with a score of $8.1 \%$ in 2016 comparative with $1.6 \%$ obtained in 2010. In Cairo, occupancy has increased in 
2016 to above $50 \%$ whilst average daily rate remained low. In Egypt the Eid al-Adha feast aided the performance of the hotels in the market.

Casablanca and Marrakeck are in the rankings on the 15th respectively 19th. In 2015, Marrakeck had a difficult year with falls in occupancy and average daily rate recording in a fall in revenue per available room of $21 \%$.

Also, Casablanca has seen a drop in performance more similar to Marrakeck. In PICBE | 1087 2015, occupancy fell slightly and average daily rate was flat in local currency terms. The introduction of new branded five-star hotel like as Four Seasons Hotel Casablanca may boost the average rates up and the security situation should encourage the tourists to stay in the hotels and thus increase F\&B facilities revenue.

\section{Conclusions}

From the onset of the Arab Spring in December 2010 in Tunisia, and then expanded to other African countries, there has been numerous victims among whom tourists, military, police, politicians, journalists, business people, educators, women and children.

Intensification of terrorist attacks led to a decrease a number of tourists visiting these countries. For Egypt, Morocco and Tunisia tourism is one of the most important sources of income and the main reason for why tourists choose to visit these countries. If in the next years the terrorist attacks will continue not only the tourism will be affected, but also air and road transport industry. The hotel industry will also be affected, and this can lead to higher unemployment.

\section{References}

Alexander, D. (2016). "Terrorism in North Africa and the Sahel in 2015", Seventh Annual Report, Inter-University Center for Terrorism Studies.

Baker, D. (2014). "The Effects of Terrorism on the Travel and Tourism Industry", International Journal of Religious Tourism of Pilgrimage, Vol. 2, No. 1,pp. 16-17.

DePuma, C.M. (2015). "Terrorize Tourists: A Study of the Impact of Terrorism on Tourism", Honors Thesses, Paper 317, 6-7.

Gray, D. and Stines, M. (2012). "New Tactical Objectives for Terrorist Groups in Somalia and Yemen", Global Security Studies, 3(1), 57-58.

Lewis, B. (1995). "The Middle East. 2000 Years of History from the Rise of Christianity to the Present Day", London, Phoenix.

Stremtan, F., Susman, M. (2006). "Issues regarding terrorism impact on world tourism", Annales Universitatis Apulensis Series Oeconomica, 3(8), 2-18. 